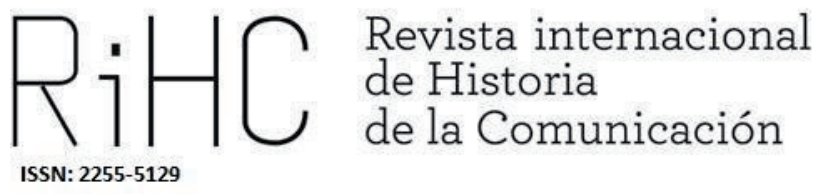

\title{
HISTORICAL VOGUE COVERS AS A SPACE FOR THE RELATIONSHIP BETWEEN ART AND ADVERTISING THROUGH FASHION
}

Las portadas históricas de Vogue como espacio de relación entre el arte y la publicidad a través de la moda

DOI: http://dx.doi.org/10.12795/RiCH.2021.i17.06

Gloria Jiménez-Marín

Universidad de Sevilla, España

gloria jimenez@us.es

ORCID (iD) 0000-0003-0252-3975

Irene González-Ariza

University of California Los Angeles, Estados Unidos

irega@ucla.edu

ORCID (D) 0000-0003-3244-2527 
Elena Bellido-Pérez

Universidad de Sevilla, España

ebellido@us.es

ORCID (D) 0000-0002-3107-5481

\begin{abstract}
The ability to inspire the fashion of the environment that surrounds it, as a science of study, as a discipline and from a psychological and sociological point of view, is not usually questioned. In this sense, the question arises about its capacity for artistic creation. Sometimes the artistic discipline is influenced by fashion and vice versa, contaminating both discourses. The present text starts from a deep analysis of the notions of art, fashion and advertising, pursuing the objective of knowing the limits that separate the general and specific characteristics of an advertising event, such as fashion shows, and those of an artistic act, from a business point of view, in the first case, and from an aesthetic point of view, in the second. To this end, a combined analysis methodology is applied, by means of a quantitative and qualitative study, in which we use a methodological triangulation of the artistic past of the magazine Vogue and the relations that have arisen thanks to the work of certain visual artists who left their mark on the covers of the magazine. The results show the intertextual relations and interrelations between the disciplines.
\end{abstract}

Keywords: Advertising, art, covers, fashion, historical, intertextuality, Vogue.

Resumen: La capacidad de inspirar la moda del entorno que le rodea, como ciencia de estudio, como disciplina y desde un punto de vista psicológico y sociológico, no suele cuestionarse. En este sentido, surge la pregunta sobre su capacidad de creación artística. En ocasiones, la disciplina artística se ve influenciada por la moda y viceversa, contaminando ambos discursos. El presente texto parte de un análisis profundo de las nociones de arte, moda y publicidad, persiguiendo el objetivo de conocer los límites que separan las características generales y específicas de un evento publicitario, como son los desfiles de moda, y las de un acto artístico, desde un punto de vista empresarial, en el primer caso, y desde un punto de vista estético, en el segundo. Para ello, se aplica una metodología de análisis combinada, mediante un estudio cuantitativo y cualitativo, en el que se utiliza una triangulación metodológica del pasado artístico de la revista Vogue y las relaciones surgidas gracias al trabajo de determinados artistas plásticos que dejaron su huella en las portadas de la revista. Los resultados muestran las relaciones intertextuales y las interrelaciones entre las disciplinas.

Palabras Clave: Arte, histórico, intertextualidad, moda, portadas, publicidad, Vogue.

\title{
Introduction
}

Fashion industry hides a historical, cultural and sociological phenomenon that is presented, on many occasions, through itself and, in so many others, through its advertising. On the other hand, art is understood as a human expression with an aesthetic and/or communicative purpose. 
In a relationship between both disciplines, can fashion be art? One of the most frequently discussed questions in the fashion and advertising industry is where the limit of both with respect to the notion of art is.

Throughout its existence, art has been conveniently used as a tactic within the global strategy devised by advertising departments and agencies, as well as industry, when addressing the emotional part of the human being, as authors such as Pérez (2000), Hetsroni and Tucachinski (2005), Miller (2007), Jiménez-Marín (2012) or Bellido-Pérez (2017) already point out. In this way, to delve into the artistic strategies followed by the industry is to complete the web of relationships that have traditionally existed between art and advertising.

To describe these strategies, we start from a fundamental base already proposed by Eco (1990, 2005), Berger (1976), Panofsky (1987), Read (1973), Dewey (2008), or, even, most recently, Jiménez-Marín and Elías (2019): Art is communication. And what does art communicate? It produces pleasure, emotion or impact on the viewer, which leads to a potential for persuasion used to persuade the client through emotion, pleasure or causing a visual impact. In this sense, the relationship between art, fashion, and advertising can be traced, as they represent visual experiences for the public.

In fact, it can be said that the strong expansion of the consumer society means that many museums are already adopting some characteristics of the commercial space, as well as marketing strategies. And vice versa: the clothing industry is turning to the various artistic disciplines for various purposes, with economic objectives and economic profitability among the former, as was already perceived in 1997 (Guidieri), and as has recently continued to be verified (Parres, García and Rodríguez-Peral, 2020). Truly, some companies expose their products as if they were works of art, recreating in their establishments a museum atmosphere. Because of this reality, "all department stores will become museums and all museums will become department stores", Warhol's phrase that is truly present (Bellido-Pérez, 2017: 113). This powerful dialogue between art and commercial industry also occurs in the opposite sense, as Warhol also predicted: it now speaks of art as a resource.

On the other hand, fashion and advertising have a very close relationship, they share many points, both disciplines being social facts and communicators, fundamental pillars of a society based on image (Pedroni and Volonté, 2014, 2012). The possibility is raised that the fashion designated as art is an advertising strategy to position the brand, without question that, in fact, fashion can adopt the art form. 


\section{Objectives}

The objective of this work is twofold: On the one hand, to discover the limits that separate the general and specific characteristics of an advertising event such as fashion shows (from a business point of view), and the characteristics of an artistic act (from an aesthetic point of view and the diffusion of arts, artists and currents). On the other hand, to know the double functionality of the covers of a historical fashion magazine, at an international level, such as Vogue, as an advertising support for artists; and, therefore, to find out how the covers of the same have meant an advertising medium, as well as a canvas, for artists (fundamentally painters) of the different periods and stages of the publication (Llorente and Díaz, 2018).

The work aims to know the artistic discourses emitted in the catwalks and analyze from the perspective of creativity, strategic planning and profitability of companies, through brands and designers who participate in the catwalks and who represent a reference where the concepts of art, fashion, and advertising come together, in line with Guerrero and Barreiro (2019).

In the same way, and in addition to analysing the limits between the conceptualisation of fashion, art and advertising, the aim is to find out how brands use art in areas such as fashion and its communication, to check the importance that various fashion magazines have had in the conception of fashion as art and vice versa, to analyze how fashion uses art and how it can become an artistic discipline.

In the end, this analysis aims to provide a model of code and style that is currently achieving the penetration of art in the fashion industry. In this way, we will see what their keys and success are.

Specifically, this research raises:

- 01 : Unveil the effects of using art in products that are in principle non-art: Analyze a representative sample, at the level of notoriety, of fashion shows with artistic incursions to find out the limits between the concepts of art and advertising.

- O2: To know the intertextual relations between both discourses: the artistic and the advertising.

- O3: Expose the relationship between the printed advertising format and art throughout history with an iconic case such as Vogue magazine. 


\section{Research questions}

The intertextuality of discourses seeks a specific objective that, on many occasions, pursues economic profitability (Marzal and Casero, 2017). The artistic discourse overturned, as is the case, to a publication, a magazine, can respond to a certain need of audiences on issues such as the artistic sensibility of fashion (Bellido-Pérez, 2017) or the possibility of disseminating art through mass magazines (Jiménez-Marín and Elías, 2019), causing the dissemination of both arts and impacting the profitability of the company in question that publishes the magazine (Condé Nast) and, as an indirect cause, on the advertising companies themselves, and/or on the artists (De Vicente, 2013). In this context, the following research questions are posed:

- RQ1: Is there a relationship between fashion brands and art from an advertising point of view?

- RQ2: What are the consequences of using art in advertising?

- RQ3: What are the intertextual relationships between artistic and advertising discourses?

In order to respond to these premises, a methodology of combined phases is designed, which is detailed below.

\section{Literature review}

\subsection{Advertising and art: historical relationship}

Advertising and art are closely related due to their historical context, among other issues. The development of advertising is largely due to the development of painting and, in particular, posters. In fact, authors such as Checa (2007: 62) go so far as to define advertisements by their artistic dimension: "Colour has made the miracle of giving the advertisement, in all its variants, expectant artistic attention".

With the birth of the contemporary poster, a new model of painting was imposed that was used by multiple artists. In this sense, Jules Cheret became the promoter of current advertising, but also of the poster, as the Czech himself states: "Bal Valentino of 1867, is the starting point of the poster as we know it today" (2007: 62).

Cheret is just one example of the many artists who joined advertising as a way of expressing their art. Many other painters made their living working in advertising and pouring their vision of artistic work on advertising posters. 
Coronado (2002) already referred to the dimensions of this artistic and advertising revolution. The phenomenon was global; it was so important that at the end of the 19thcentury cities such as Paris or Italy were wallpapered with posters, a fact that led to the prohibition of placing outdoor advertising. In fact, "talented artists such as Alphonse Mucha in France, Joseph Steiner in Germany, Aubrey Beardsley in the United Kingdom, Will Bradley in the United States and Leonetto Capiello in Italy, will abandon the canvas in favor of pencil and poster painting" (Coronado, 2002: 91).

Moreover, following this same author, and in order to understand the strong historical relationship that exists between art and advertising, it is indispensable to mention Henri Toulouse-Lautrec, the father of the poster understood as a work of art "because, from him, advertising will embrace the artistic medium as its own language that would best serve to advance over time, adapting to successive changes in styles" (Coronado, 2002: 91).

The importance of Toulouse-Lautrec lies in his role as a painter who manages to link the artistic aspect of the poster with the commercial tone of advertising. With ToulouseLautrec, art and advertising become one: the artist begins a new pictorial movement through advertising, his works being commercial pieces. At this moment there is no distinction between advertising and art, each discipline feeds on the other to achieve its individual objectives: On the one hand, the commercial side of the work fulfills the objective of attracting the attention of the public, and on the other, the artistic side manages to move the public.

Thus, at the end of the 19th century and the beginning of the 20th century, many artists were attracted by advertising as a means of investing in their works. And, in this way, different artistic movements will be developed through the advertising format. Thus, the new techniques were welcomed; just as painters used advertising as work to continue creating, many photographers turn to advertise for the same reason. They used their talent for campaigns while developing new, more artistic techniques that they would later use in advertisements. Thus, many photographers become advertising designers who would delegate their artistic point of view to the advertisements, just as painters did.

Likewise, with the advent of the avant-garde and other artistic movements, advertising was influenced by these new discourses (Sánchez, 2021). For the avant-gardes, the result of the work was not as important as the process of creation. From this moment on, the elements included in the work became more important than the work as a whole. Pérez (1998: 183) stated that "the painting ceases to be a means of portraying reality and agrees on an end in itself, where what interests the artist are the relationships between forms, colors, textures, etc.". 
In this sense, advertising and avant-garde art were on the same path. The first at that time was based on the perfect conjunction of the elements used, a common characteristic with the avant-garde. Futurism, Dadaism, and constructivism are examples of the avant-garde that used advertising to advertise themselves as artistic movements. In this way, not only products were advertised, but also ideas and reflections. Artists such as Willen Gispen or Steven Kampmann adapted the advertising language to avant-garde works.

Once again advertising becomes a medium that directs an artistic current. This helps the new authors to develop in the movement. At the same time, they provide an advertising with the aesthetics in Vogue needed to reach an increasingly complex audience.

Moreover, pop art is the artistic current par excellence that uses advertising as a medium and format at the same time, because in this movement there is a gradual process of approach to the advertising language: English pop artists introduce elements of advertising in their paintings, where they reflect on the society in which they live, "the claims serve as a starting point or inspiration for their works" (Pérez, 1998: 185). Andy Warhol, perhaps the most recognized artist of this current, tries to give value to the new role that brands were having at the time. Thus, when he copies the soup containers, Campbell is making a metaphor about the society in which he finds himself. The making of the works becomes an advertising resource for the brand itself and yet they are the first works of art. With this current, advertisers and artists come closer to their disciplines, which begin to share a language and an iconography, while at the same time laying the foundations for new principles.

Can advertising be art and vice versa? Based on the contributions of Jiménez-Marín (2012), we can affirm that despite the undeniable historical relationship that art and advertising share, this does not answer one of our questions: can art be advertising? And vice versa? Faced with this question, many scholars of advertising and art speak out. Pérez, who comes to express that art is not advertising because "its function is commercial" (1998: 4), to Hagdtvedt and Patrick (2008a, 2008b), who affirm this argument in the same line.

However, in both disciplines there are points of connection that link them, perceiving in certain artistic movements a predisposition to use original procedures and techniques of advertising language, as in advertising can be seen cases of speeches that try to approach art.

Art can become advertising and vice versa. An example of this is Picasso's Guernica, which became one of the best advertising campaigns of the Spanish Civil War and Spain at the time. The Guernica was made by the artist from Malaga as a commission from the government of the republic with the aim of transmitting the barbarity of the war and was exhibited at the International Exhibition in Paris in 1937. Along the same lines, it can 
be said that advertising also becomes art; this is the case of the propaganda poster made by the United States of Uncle Sam during the First World War. The poster, which was intended for young Americans to enlist in the army, has eventually become an art piece.

Advertising works lose their commercial side over time. Leaving aside their objective of attracting the public, they are transformed into images whose function is solely artistic. In this way, artistic images and advertising are at the same level of analysis: "the use of painting and techniques associated with the primitive commercial poster would be prolonged" (Coronado, 2002: 158) and advertising "ceases to be an individual creative process, as art is, and becomes a language, such as cinema, in which authorship is shared among many people" (Pérez, 1998: 187).

\subsection{Relationship between art and fashion}

Fashion and art have been related for centuries. This is due to their creative involvement, one of the characteristics of art (Pedroni and Volonté, 2014, 2012). In recent decades different authors have proclaimed textile design as one more art.

With social progress, new technologies and the consolidation of the bourgeois class, fashion begins to be valued as a model of sophistication associated with art and culture. This is largely due to the birth of fashion magazines, as expressed by Gallego (1990). It should be borne in mind that in earlier times the conception of fashion was associated with the high spheres, where art was very familiar.

One of the first cases in which art began to be influenced by fashion was with the presentation in 1901 of Victor Prouvé's spring riverbank dress in 1901 (Image 1).

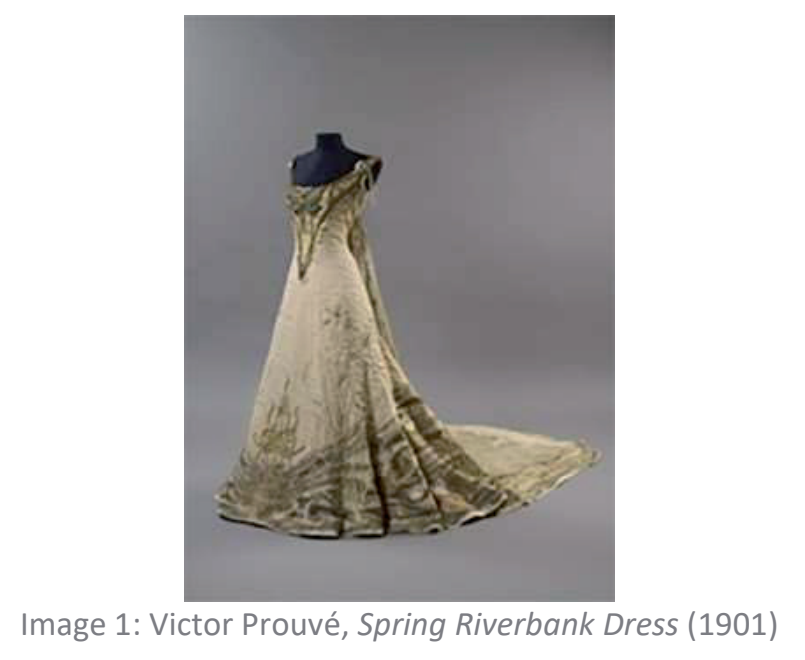

With this name, the dress inevitably suggests vegetal ornamentation (Eguizábal, 2008: 26). The vegetable came into Vogue through a movement of return to nature initiated by Rousseau. 
When comparing art and fashion, the first thing that emerges is the capitalist character of the latter. It is impossible to deny the commercial vocation of the creation of clothing. However, it should be remembered that even the most important artists sell their art to museums or galleries, just as the clothing industry sells its costumes to the public. Erner is vehemently opposed to this: "To compare a dress with painting would be a demagogic temptation, whereby any kind of popular expression could be considered art. At best, textile creation is granted the status of minor art" (2005: 40).

In this sense, it should be noted that the so-called 'minor art' referred to by Erner is to be found in the major museums. In fact, the Guggenheim Museum in New York, and later in Bilbao, hosted an exhibition commemorating the 25th anniversary of Giorgio Armani, which was attended by more than 300,000 visitors. Similarly, the Museum of Modern Art in Vienna (MUMOK) held an exhibition in 2012 entitled Reflecting Fashion: Art and Fashion from Modernism, which reflected the work of different designers. This exhibition documented the collaboration between the two creative fields, with a clear twinning from the eighties of the twentieth century and its extension to the present day.

Similarly, we cannot underestimate the growing importance and relevance that, from a historical and anthropological point of view, fashion museums such as the Ferragamo Museum (Florence, Italy), the Christian Dior Museum (Granville, France), the Museo del traje in Madrid (Spain), the Bata Shoe Museum (Toronto, Canada), the Museo Cristóbal Balenciaga (Getaria, Spain), the Museo Gucci (Florence, Italy) or the Fondation Pierre Bergé-Yves Saint Laurent (Paris, France and Marrakech, Morocco). Along these lines, it is also necessary to appreciate the permanent exhibition at the Metropolitan Museum of Art (New York, USA) of The Anna Wintour Costume Center or the exhibition, also perennial, at the New York's Fashion Institute of Technology (New York, USA).

The creations of Gustav Klimt and Emile Flöge were based on the liberating movement of women regarding the use of corsets. Thus, they created broad robes for both men and women, fleeing the oppression of the moment. This fact demonstrates, as mentioned above, that art reflects the context in which it is created, acting as a mirror of the society of the moment. Following this trend of the modern woman, Sonia Delaunay, painter and designer, captured abstract motifs through painting in her designs. In this way, she combined painting and textiles for the creation of her works.

The emergence of styles, movements, and trends is one of the reasons why the suit is claimed to be an art, demonstrating the adoption of romantic movements in clothing, oriental influences and even the power-flower-hippy movement of the 1960s. In this sense, Laver indicates that "for the fashion designers of the 1960s, the body was a design object, a human canvas in which any feeling or idea could be captured" (1988: 264).

The avant-garde and pop art may be the artistic movements that have most influenced the textile work. See for example Giacomo Balla, a futuristic painter who in 1914 created 
a suit with geometric figures and warm tones, which clearly feeds on the avant-garde (Image 2).

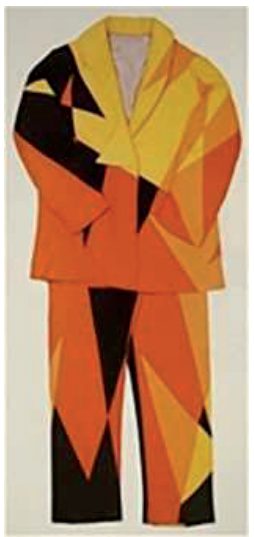

Image 2: Futuristic costume, by Giacomo Balla (1914)

Elsa Schiaparelli, in collaboration with Salvador Dalí, also created the Lobster Dress in 1937 (Image 3).

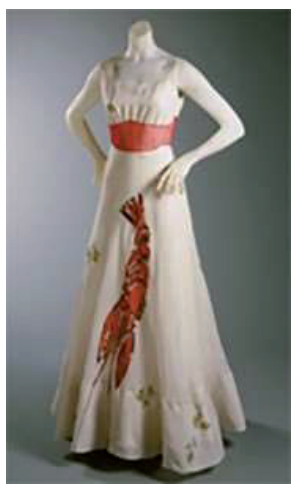

Image 3: Lobster Dress, by Salvador Dalí (1937).

Yves Saint Laurent's Mondrian Dress (1960) (Image 4), with neoplastic inspiration, also sets an example in this line, following the design drawn by the Dutch painter Piet Mondrian, where the dress functions as a canvas.

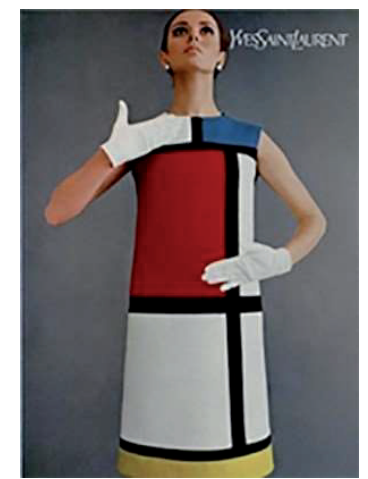

Image 4: Mondrian Dress, by Yves Saint Laurent (1960) 
As for pop art, it's impossible not to mention Andy Warhol's work. His works have inspired many maisons and designers in the creation of designs driven by pop culture, such as the Campbell Dress, designed by De Castelbajac in 1984 (Image 5).

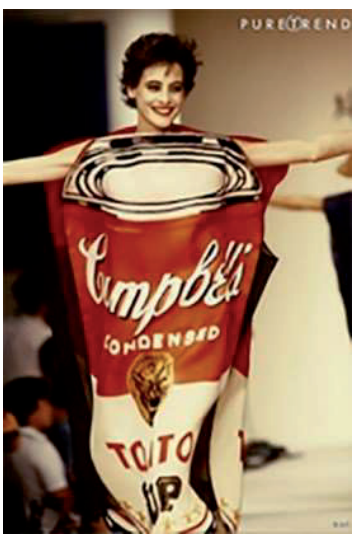

Image 5: Campbell Dress, by De Castelbajac (1984)

In this sense, "art has changed its function: it brings to man the aesthetics of distraction, admirably concentrated in Warhol's work, so popular in the world of fashion" (Erner, 2005: 45).

The list of relationships between real art, what is socially accepted as real art, and fashion continue to this day. In 2017 Chanel's creative director and designer, Karl Largerfeld created a Greek-inspired clothing line. As Ortega y Gasset says "it is not easy to exaggerate the influence that the past always has on the future of art" (1981: 44).

Several scholars claim that fashion is a cultural fact, but not art. Since the second half of the 20th century, fashion has been presented as a new discourse, artistic in this case, and as a new way for artists to express their thoughts. Since the twenty-first century, the limits of what is considered art are blurred and the dress is discovered as a possible synonym for artistic expression.

Art feels linked to its context, just as fashion does. Disciplines translate into a way of seeing the reality in which their artists find themselves; both, in many ways, are oriented towards the public. The art looks for impossible forms, marked or invisible strokes. As in other arts, not all fashion is art, but it can become art. In other words, "if anything defines fashion it is symbolism and its unpredictability... As in art, fashion laws do not exist" (Dorfles, 2002: 14).

\subsection{Advertising and fashion}

Fashion is essentially communication (Squicciarino, 1990). When you decide to dress one way or another, you are making the decision to communicate who you are through different brands, styles or garments. In this sense, fashion reflects the characteristics of the human being (Lurie, 2013). 